War, Culture and Society, 1750-1850

Series Editors: Rafe Blaufarb (Tallahassee, USA), Alan Forrest (York, UK), and Karen Hagemann (Chapel Hill, USA)

Editorial Board: Michael Broers (Oxford, UK), Christopher Bayly (Cambridge, UK), Richard Bessel (York, UK), Sarah Chambers (Minneapolis, USA), Laurent Dubois (Durham, USA), Etienne François (Berlin, Germany), Janet Hartley (London, UK), Wayne Lee (Chapel Hill, USA), Jane Rendall (York, UK), Reinhard Stauber (Klagenfurt, Austria)

Titles include:

Richard Bessel, Nicholas Guyatt and Jane Rendall (editors)

WAR, EMPIRE AND SLAVERY, 1770-1830

Eveline G. Bouwers

PUBLIC PANTHEONS IN REVOLUTIONARY EUROPE

Comparing Cultures of Remembrance, c.1790-1840

Michael Broers, Agustin Guimera and Peter Hick (editors)

THE NAPOLEONIC EMPIRE AND THE NEW EUROPEAN POLITICAL CULTURE

Gavin Daly

THE BRITISH SOLDIER IN THE PENINSULAR WAR

Encounters with Spain and Portugal, 1808-1814

Charles J. Esdaile and Philip Freeman

BURGOS IN THE PENINSULAR WAR, 1808-1814

Occupation, Siege, Aftermath

Alan Forrest, Etienne François and Karen Hagemann (editors)

WAR MEMORIES

The Revolutionary and Napoleonic Wars in Modern European Culture

Alan Forrest, Karen Hagemann and Jane Rendall (editors)

SOLDIERS, CITIZENS AND CIVILIANS

Experiences and Perceptions of the Revolutionary and Napoleonic Wars, 1790-1820

Alan Forrest and Peter H. Wilson (editors)

THE BEE AND THE EAGLE

Napoleonic France and the End of the Holy Roman Empire, 1806

Rasmus Glenthøj and Morten Nordhagen Ottosen

EXPERIENCES OF WAR AND NATIONALITY IN DENMARK AND NORWAY, 1807-1815

Karen Hagemann, Gisela Mettele and Jane Rendall (editors)

GENDER, WAR AND POLITICS

Transatlantic Perspectives, 1755-1830 
Leighton James

WITNESSING THE REVOLUTIONARY AND NAPOLEONIC WARS IN GERMAN

CENTRAL EUROPE

Catriona Kennedy

NARRATIVES OF THE REVOLUTIONARY AND NAPOLEONIC WARS

Military and Civilian Experience in Britain and Ireland

Catriona Kennedy and Matthew McCormack (editors)

SOLDIERING IN BRITAIN AND IRELAND, 1750-1850

Men of Arms

Ralph Kingston

BUREAUCRATS AND BOURGEOIS SOCIETY

Office Politics and Individual Credit, France 1789-1848

Mark Lawrence

SPAIN'S FIRST CARLIST WAR, 1833-40

Kevin Linch

BRITAIN AND WELLINGTON'S ARMY

Recruitment, Society and Tradition, 1807-1815

Pierre Serna, Antonino De Francesco and Judith Miller

REPUBLICS AT WAR, 1776-1840

Revolutions, Conflicts and Geopolitics in Europe and the Atlantic World

Marie-Cécile Thoral

FROM VALMY TO WATERLOO

France at War, 1792-1815

Mark Wishon

GERMAN FORCES AND THE BRITISH ARMY

Interactions and Perceptions, 1742-1815

Christine Wright

WELLINGTON'S MEN IN AUSTRALIA

Peninsular War Veterans and the Making of Empire c.1820-40

War, Culture and Society, 1750-1850

Series Standing Order ISBN 978-0-230-54532-8 hardback

978-0-230-54533-5 paperback

(outside North America only)

You can receive future titles in this series as they are published by placing a standing order. Please contact your bookseller or, in case of difficulty, write to us at the address below with your name and address, the title of the series and one of the ISBNs quoted above.

Customer Services Department, Macmillan Distribution Ltd, Houndmills, Basingstoke, Hampshire RG21 6XS, England 


\title{
Burgos in the Peninsular War, 1808-1814
}

\section{Occupation, Siege, Aftermath}

\author{
Charles J. Esdaile
}

Professor in History, University of Liverpool, UK

Philip Freeman

Senior Lecturer in Archaeology, University of Liverpool, UK 


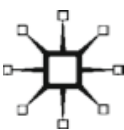

(c) Charles J. Esdaile and Philip Freeman 2015

Softcover reprint of the hardcover 1st edition 2015 978-1-137-43289-6

All rights reserved. No reproduction, copy or transmission of this publication may be made without written permission.

No portion of this publication may be reproduced, copied or transmitted save with written permission or in accordance with the provisions of the Copyright, Designs and Patents Act 1988, or under the terms of any licence permitting limited copying issued by the Copyright Licensing Agency, Saffron House, 6-10 Kirby Street, London EC1N 8TS.

Any person who does any unauthorized act in relation to this publication may be liable to criminal prosecution and civil claims for damages.

The authors have asserted their rights to be identified as the authors of this work in accordance with the Copyright, Designs and Patents Act 1988.

First published 2015 by

PALGRAVE MACMILLAN

Palgrave Macmillan in the UK is an imprint of Macmillan Publishers Limited, registered in England, company number 785998, of Houndmills, Basingstoke, Hampshire RG21 6XS.

Palgrave Macmillan in the US is a division of St Martin's Press LLC, 175 Fifth Avenue, New York, NY 10010.

Palgrave Macmillan is the global academic imprint of the above companies and has companies and representatives throughout the world.

Palgrave ${ }^{\circledR}$ and Macmillan ${ }^{\circledR}$ are registered trademarks in the United States, the United Kingdom, Europe and other countries.

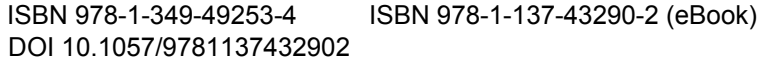

This book is printed on paper suitable for recycling and made from fully managed and sustained forest sources. Logging, pulping and manufacturing processes are expected to conform to the environmental regulations of the country of origin.

A catalogue record for this book is available from the British Library.

A catalog record for this book is available from the Library of Congress. 
In memory of Sergeant James Foyer, 42nd Regiment of Foot, killed in action, Burgos, 19 September 1812 
This page intentionally left blank 


\section{Contents}

List of Figures viii

Series Preface $\quad$ ix

Preface and Acknowledgements xi

1 Sources and Questions 1

2 Beginnings 17

3 Occupation 41

4 The March $\quad 65$

5 The Siege 84

$\begin{array}{ll}\text { Postscript: } 1813 \text { and After } & 126\end{array}$

Appendix 1: The Archaeology 136

Appendix 2: The Cartography 142

Appendix 3: The Fortress of Burgos Today 156

$\begin{array}{ll}\text { Notes } & 160\end{array}$

$\begin{array}{lr}\text { Select Bibliography } & 207\end{array}$

$\begin{array}{ll}\text { Index } & 214\end{array}$ 


\section{Figures}

2.1 Spain and Portugal; author's collection 18

2.2 Central Spain; author's collection 19

A2.1 'Attack of the castle of Burgos between the 19th of September and the 21st October 1812' (i.e. the 'Jones map'); reproduction courtesy of the Sydney Jones Library, University of Liverpool

A2.2 Profiles drawn up by J.T. Jones to illustrate the 'Jones map'; reproduction courtesy of the Sydney Jones Library, University of Liverpool

A2.3 Plan del fuerte de Burgos y proyecto de rectificación, 1811; reproduction courtesy of Instituto de Historia y Cultura Militar (Madrid)

A2.4 Plan du chateau de Burgos relatif a la défense faite par les français en 1812 (i.e. the 'Barrière map'); reproduction courtesy of Instituto de Historia y Cultura Militar (Madrid)

A2.5 The 'Jones map' as repackaged by William Napier, 1834; reproduction courtesy of the Sydney Jones Library, University of Liverpool

A2.6 The 'Jones map' as repackaged by John Wyld, 1840; reproduction courtesy of Richard Tennant

A2.7 The 'Jones map' as repackaged by Charles Oman, 1922; author's collection

A2.8 The 'Jones map' as repackaged by Ian Fletcher, 2003; reproduction courtesy of Osprey Books

A2.9 The 'Barrière map' as repackaged by John Fortescue, 1912; reproduction courtesy of the Napoleon Series

A2.10 The 'Barrière map' as repackaged by Nick Lipscombe, 2010; reproduction courtesy of Osprey Books 


\section{Series Preface}

The century from 1750 to 1850 was a seminal period of change, not just in Europe but across the globe. The political landscape was transformed by a series of revolutions fought in the name of liberty - most notably in the Americas and France, of course, but elsewhere, too: in Holland and Geneva during the eighteenth century and across much of mainland Europe by 1848. Nor was change confined to the European world. New ideas of freedom, equality and human rights were carried to the furthest outposts of empire, to Egypt, India and the Caribbean, which saw the creation in 1801 of the first black republic in Haiti, the former French colony of Saint-Domingue. And in the early part of the nineteenth century they continued to inspire anticolonial and liberation movements throughout Central and Latin America.

If political and social institutions were transformed by revolution in these years, so, too, was warfare. During the quarter-century of the French Revolutionary Wars, in particular, Europe was faced with the prospect of 'total' war, on a scale unprecedented before the twentieth century. Military hardware, it is true, evolved only gradually, and battles were not necessarily any bloodier than they had been during the Seven Years War. But in other ways these can legitimately be described as the first modern wars, fought by mass armies mobilised by national and patriotic propaganda, leading to the displacement of millions of people throughout Europe and beyond, as soldiers, prisoners of war, civilians and refugees. For those who lived through the period these wars would be a formative experience that shaped the ambitions and the identities of a generation.

The aims of the series are necessarily ambitious. In its various volumes, whether single-authored monographs or themed collections, it seeks to extend the scope of more traditional historiography. It will study warfare during this formative century not just in Europe, but in the Americas, in colonial societies and across the world. It will analyse the construction of identities and power relations by integrating the principal categories of difference, most notably class and religion, generation and gender, race and ethnicity. It will adopt a multifaceted approach to the period, and turn to methods of political, cultural, social, military and gender 
x Series Preface

history, in order to develop a challenging and multidisciplinary analysis. Finally, it will examine elements of comparison and transfer and so tease out the complexities of regional, national, European and global history.

Rafe Blaufarb, Alan Forrest and Karen Hagemann 


\section{Preface and Acknowledgements}

Spain is a country liberally bespattered with reminders of a bloodstained past. Enormous fortresses dominate the skylines of such places as Granada, Sagunto, Alicante and Málaga; castles dot the hilltops of the meseta; Iron Age forts bestrew the mountains of the maestrazgo; and here and there cities retain either the full circuit of their mediaeval walls (Ávila) or the bastioned defences of a later age (Badajoz and Ciudad Rodrigo). In many cases, however, these relics are poorly presented, with little in the way of explicative signage or commemoration of any sort, or, at best, a very partial representation of their history, while in others they lie forgotten and at risk. How many residents of Madrid, for example, know that within a mile of the centre of the city are to be found trench systems as elaborate as anything to be seen on the Western Front? In the case of such relics of the Civil War of 1939, this occlusion is understandable, indeed, perhaps even necessary, but with earlier conflicts political factors do not apply with quite the same strength, and therefore it is puzzling that so many historical sites go all but unnoticed, let alone exploited for the purposes of heritage tourism. In this work the story is told of the rediscovery of one such site, and the manner in which the intensive study of the extraordinary remains that it offers has facilitated a study of the most dramatic episode in its history.

The site referred to is that of the fortress constructed by the forces of Napoleon around the nucleus constituted by the mediaeval castle that overlooks the city of Burgos. In the autumn of 2008 a visit to Burgos revealed, first, that, though obscured by dense forest, large parts of the earthwork defences that made up the bulk of the defence works have withstood the test of time, and, second, that there was only limited understanding of the site at the local level. As even preliminary reading revealed, meanwhile, there were numerous unanswered questions respecting the standard accounts of the siege of September-October 1812 that marked the highpoint of the fortress's experience of the Peninsular War as well as substantial contradictions in the mapping of the site. There followed the formation of the small research team represented by the authors of this work, and over the course of the period 
2009-2010 a series of field trips was organised in which every part of the site was extensively explored and the defences plotted and photographed in minute detail. With the co-operation of the city museum the opportunity was taken to view the wide range of artefacts excavated at different points of the site in small archaeological excavations conducted in 1991 and 2008, while an intensive study was undertaken of the available cartography. Finally, hitherto unexplored documentary resources including such material as wills, casualty returns and unpublished memoirs were located and analysed, all this data then being integrated with the numerous contemporary accounts of the siege to produce a picture of events that has afforded fresh insights into the historical narrative, not to mention a greater understanding of the nature of the fortifications.

To all this, it will be objected that Burgos in the Peninsular War, 1808-1814 does no more than revisit ground that has already been much fought over. Though an extremely significant incident, the siege of Burgos is not an episode that has received much attention from scholars. Whilst it occupies its due place in biographies of the Duke of Wellington (e.g. Longford, Muir), in all the chief histories of the campaigns waged by the Anglo-Portuguese army (e.g. Napier, Oman, Fortescue, Davies) and, for that matter, studies of British sieges in the Peninsula (e.g. Jones, Myatt, Fletcher), unlike, say, the earlier siege of Badajoz, it has never been the subject of a discreet monograph. For this there are two reasons: first of all, the siege was a resounding failure that cost over 2,000 Anglo-Portuguese casualties, together with another 5,000 in the disastrous retreat that followed, and, second of all, because careful analysis of what took place suggests that the chief culprit was none other than Wellington himself rather than the factors - want of means, the mistakes of the Royal Engineers and the failings of the troops engaged in the siege - on which the British commander was inclined to blame his predicament. The absence of such an analysis of the siege, however, is most unfortunate. Setting aside the fact that it would shed fresh light on a figure about whom there might seem to be little new to say, Wellington's failure at Burgos precipitated a major crisis in Anglo-Spanish relations that could easily have jeopardised the success of the campaigns of 1813. Clearly, then, Burgos is worth looking at.

However, the history of any fortress is not just limited either to the battles and sieges that centred on its walls or to the changing configuration of its profile. Such features of the landscape also have a political, social and geographical context, and care has therefore been taken to 
extend the coverage offered by this work to the city of Burgos and, more particularly, the manner in which its population experienced the French occupation of 1808-1813, this last being especially oppressive: of all Spain's provincial capitals, only Barcelona, Pamplona, San Sebastián and Vitoria were in the hands of the invaders for a longer period of time, whilst few others experienced such utter devastation. It is hoped, then, that this work will not just be seen as one more exercise in 'drum and trumpet' history, but rather that it will also be taken as a reminder that war is about civilians as well as soldiers, and, further, that it is invariably civilians who bear the brunt of the suffering.

Turning to brighter matters, the authors are in debt to many people. Chief among these is Ana Ortega Martínez, a leading archaeologist of Burgos and its environs who has throughout been completely unstinting in her kindness and generosity: without her, indeed, it is doubtful that this work could ever have been written. Closely following her come a number of junior scholars who have been closely associated with us at various points during our research, including, most notably, Michael McDonagh and Berta Guinea Izquierdo, as well as the artist responsible for the front cover, Helen Esdaile. And, were it not for the interest and encouragement of Alan Forrest of the University of York, not to mention Jenny McCall and Holly Tyler of Palgrave Macmillan, it is impossible to see how our efforts could have seen the light of day in so short a time. Equally, without the financial support received from the University of Liverpool, the fieldwork upon which this project rests would never have been translated into reality, whilst our thanks also go to the various archives and other agencies from whom permission has been received to quote from or otherwise utilise material that is in copyright, namely the National Archives, the British Library, the University of Liverpool, the University of Southampton, the University of Manchester, the Instituto de Historia y Cultura Militar, the Archivo Municipal de Burgos, the Napoleon Series and the estate of Earl Grey of Howick (particular thanks are also due to the staff of the Sydney Jones Library of the University of Liverpool for their help in reproducing a number of the figures, and to Nick Lipscombe, Robert Burnham of the Napoleon Series, Elinor Vickers of National Trust Scotland, and Richard Sullivan of Osprey Books). But, most of all, standing firm beside us and tolerating our many absences in the field over a period that all but exactly mirrors the length of the conflict we have been studying, there are Alison and Lorraine, of whom the latter has provided not only moral support, but also considerable practical assistance with our mapping, whilst also enduring, along with the Wee Three Glasgee 
Thuggee Boys, many hours of wandering the lumps and bumps of the Cerro de la Blanca and the Cerro de San Miguel. To all concerned, then, exactly 201 years on from the end of the siege of 1812, our grateful thanks.

Charles J. Esdaile and Philip Freeman 